\title{
PENGARUH DISKRIMINASI GENDER DALAM KELUARGA TERHADAP PEMILIHAN PENOLONG PERSALINAN DI KECAMATAN BANDAR PULAU KABUPATEN ASAHAN TAHUN 2013
}

\author{
Irma Linda, Arihta Sembiring, Firiyani Pulungan \\ Jurusan Kebidanan Politeknik Kesehatan Kemenkes Medan
}

\begin{abstract}
Abstrak
Pertolongan persalinan oleh tenaga kesehatan terlatih merupakan salah satu cara paling efektif dalam upaya menurunkan Angka Kematian Ibu (AKI), oleh karena itu sasaran dari pembangunan kesehatan salah satunya adalah meningkatnya secara bermakna jumlah ibu hamil yang memeriksakan diri dan melahirkan ditolong oleh tenaga kesehatan. Pada tahun 2010 di Kecamatan Bandar Pulau terdapat 2 orang ibu bersalin dan 1 orang ibu masa nifas meninggal. Hal ini disebabkan oleh karena persalinan di tolong oleh dukun (Profil kesehatan Puskesmas Aek Songsongan, 2010).Tujuan penelitian ini untuk menganalisis pengaruh diskriminasi gender dalam keluarga (aksespelayanan kesehatan dan pengambilan keputusan) terhadap pemilihan penolong persalinan di Kecamatan Bandar Pulau Kabupaten Asahan tahun 2013. Jenis penelitian ini merupakan survei analitik dengan pendekatan explanatory research yang bersifat Cross Sectional yang dilakukan di Kecamatan Bandar Pulau Kabupaten Asahan 2013. Penelitian dilaksanakan mulai Bulan Juli sampai dengan bulan September tahun 2013. Populasi dalam penelitian ini adalah seluruh ibu bersalin dalam 3 bulan terakhir yang berdomisili di Kecamatan Bandar Pulau Kabupaten Asahan dengan besar sampel 94 orang. Penentuan sampel secarapurposive sampling. Untuk menganalisis pengaruh diskriminasi gender dalam keluarga (akses pelayanan kesehatan danpengambilan keputusan) terhadap pemilhan penolong persalinan digunakan uji regresi logistik ganda. Hasil penelitian menunjukkan ada pengaruh diskriminasi gender dalam keluarga aspek akses pelayanan kesehatan terhadap pemilihan penolong persalinan di kecamatan Bandar Pulau kabupaten Asahan tahun $2013(p=0,030)$ dengan nilai koefisien regresi=-1,588, sehingga dapat dinyatakan bahwa bahwa diskriminasi gender dalam keluarga aspek akses ke pelayanan kesehatan yang kurang baik akan meningkatkan angka pertolongan persalinan dengan non tenaga kesehatan. Sedangkan diskriminasi gender dalam keluarga aspek pengambilan keputusan tidak berpengaruh secara bermakna. Diharapkan pada pengambil kebijakan di Dinas Kesehatan Kabupaten Asahan dapat merumuskan program kerja yang berperspektif gender seperti program promosi kesehatan tentang kesehatan reproduksi dan pertolongan persalinan dalam upaya pencegahan terjadinya komplikasi persalinan dan nifas serta kematian pada ibu.
\end{abstract}

Kata Kunci: Diskriminasi Gender, Penolong Persalinan

\section{PENDAHULUAN}

Pertolongan persalinan oleh tenaga kesehatan terlatih merupakan salah satu cara paling efektif dalam upaya menurunkan angka kematian ibu, oleh karena itu sasaran dari pembangunan kesehatan salah satunya adalah meningkatnya secara bermakna jumlah ibu hamil yang memeriksakan diri dan melahirkan ditolong oleh tenaga kesehatan (Bappenas, 2007).

Berdasarkan data Riskesda (2010),tahun 2002 persentase cakupan persalinan oleh tenaga kesehatan sebesar 66,7\%, tahun 2009 meningkat menjadi 77,34\% dan tahun 2010 meningkat lagi menjadi 82,3\%. Harapan pada tahun 2015 proporsi persalinan oleh tenaga kesehatan $100 \%$ menurut kesepakatan global (Millenium Development Gools).
Pertolongan persalinan oleh tenaga kesehatan di Sumatera Utara menunjukkan kecendrungan peningkatan yaitu dari 81,61\% tahun 2008, 85,93\% tahun 2009 dan 86,73\% tahun 2010. Pencapaian cakupan sangat bervariasi per kabupaten / kota namun angka ini juga belum mencapai target cakupan dalam visi Indonesia Sehat 2010 yaitu 90\% (Dinkes Provinsi Sumatera Utara, 2010).

Selain di tingkat propinsi tingginya AKI juga dapat dilihat di tingkat kabupaten seperti Kabupaten Asahan, AKI dalam tiga tahun terakhir masih tinggi. Pada tahun 2007 sebesar 6,43 per 1000 Kelahiran hidup atau 16 kematian ibu dari 24.898 kelahiran hidup, tahun 2008 sebesar 12,23 per 1000 kelahiran hidup atau 17 kematian ibu dari 13.897 kelahiran hidup, sedangkan pada tahun 2009 sebesar 11,56 per 1000 atau 19 kematian ibu dari 16.435 kelahiran hidup, berdasarkan 
data tersebut AKI di kabupaten Asahan terlihat meningkat (Dinkes Kabupaten Asahan, 2010).

Pemanfaatan bidan atau petugas kesehatan lainnya dalam Pertolongan persalinan bagi ibu bersalin di Kabupaten Asahan pada dua tahun terakhir meningkat dari 84,17\% tahun 2008 menjadi 90,23\% tahun 2009. Namun pencapaian ini juga belum sesuai harapan MDG`s (Dinkes Kab.Asahan, 2010). Pada tahun 2010 di Kecamatan Bandar Pulau terdapat 2 orang ibu bersalin dan 1 orang ibu masa nifas meninggal. Hal ini disebabkan oleh karena persalinan di tolong oleh dukun (Puskesmas Aek Songsongan, 2010).

Faktor-faktor penyebab masih tingginya AKI, pada dasarnya dapat disebabkan karena banyak masalah sosial yang terkait dengan kesejahteraan perempuan yang bermuara pada kultur patriarki. Secara tidak langsung posisi sosial perempuan yang masih mengalami subordinasi di masyarakat, memberikan sumbangan dalam kesehatan reproduksi ibu. Pemahaman pentingnya perencanaan kehamilan, pencegahan kekerasan dan pembagian peran gender dalam rumah tangga sangat berkontribusi terhadap keselamatan dan kesehatan mental dan fisik ibu hamil serta janin dalam kandungannya (Handayani dan Sugiarti, 2002).

Adanya hambatan dalam akses pelayanan terhadap pelayanan kesehatan terutama dialami oleh perempuan karena adanya status perempuan yang tidak mendapat izin dari suami serta pemegang keputusan, siapa yang menolong persalinan istri kebanyakan masih ditentukan oleh suami (Azwar, 2001), sehingga terjadi subordinasi terhadap perempuan dengan keterbatasan perempuan dalam pengambilan keputusan untuk kepentingan dirinya.

Berdasarkan hasil survey awal melalui wawancara dengan bidan desa di wilayah kerja Puskesmas Aek Songsongan, Kecamatan Bandar Pulau Kabupaten Asahan menunjukkan adanya beberapa perilaku yang menyangkut pengambilan keputusan pemilihan penolong persalinan ditentukan oleh suami dan keluarga besar.

\section{TUJUAN PENELITIAN}

Untuk mengetahui pengaruh diskriminasi gender dalam keluarga (akses pelayanan kesehatan dan pengambilan keputusan) terhadap pemilihan penolong persalinan di Kecamatan Bandar Pulau Kabupaten Asahan tahun 2013.

\section{MANFAAT PENELITIAN}

Manfaat penelitian diharapkan dapat memberikan informasi khususnya kepada pengambil kebijakan dalam pelayanan kesehatan sebagai data dan bahan masukan dalam merumuskan perencanaan kebijakan dan program kerja dalam upaya mengurangi ketidaksetaraan gender dalam bidang kesehatan.

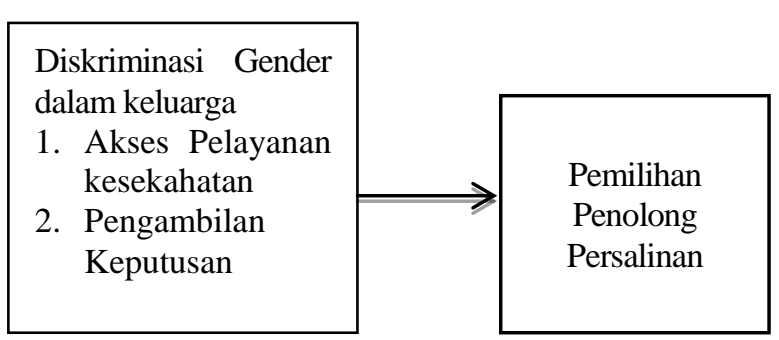

Variabel independen dalam penelitian ini adalah dikriminasi gender dalam keluarga yang terdiri dari akses pelayanan kesehatan dan pengambilan keputusan. Variabel dependen adalah pemilihan penolong persalinan.

Diskriminasi gender dalam keluarga khususnya terhadap wanita dapat dilihat melalui akses ibu ke pelayanan kesehatan yang masih dipengaruhi oleh keberadaan suami sebagai kepala rumah tangga menyangkut izin, biaya yang dibutuhkan, waktu, dan jarak ke sarana pelayanan. Pengambilan keputusan dalam memilih penolong persalinan yang merupakan hak ibu hamil atas dirinya sendiri, pada kenyataannya tidak dapat terpenuhi karena besarnya keterlibatan suami dan keluarga dalam pengambilan keputusan, hal ini akan berdampak kepada keterlambatan pertolongan terhadap gangguan dan komplikasi selama kehamilan dan persalinan.

\section{METODE PENELITIAN}

Jenis penelitian yang dilakukan adalah survei analitik dengan pendekatan explanatory research yang bertujuan untuk menganalisis pengaruh diskriminasi gender dalam keluarga terhadap pemilihan penolong persalinan.

\section{LOKASI DAN WAKTU PENELITIAN}

Penelitian dilakukan di Kecamatan Bandar Pulau Kabupaten Asahan dengan alasan bahwa di lokasi tersebut masih didapatkan persalinan yang ditolong oleh bukan tenaga kesehatan dan keputusan pemilihan penolong persalinan masih didominasi oleh suami dan keluarga besar. Penelitian dilakukan mulai bulan Juli sampai dengan September 2013.

\section{POPULASI DAN SAMPEL}

Populasi dalam penelitian ini adalah seluruh ibu bersalin dalam 3 bulan terakhir yang berdomisili di Kecamatan Bandar Pulau Kabupaten Asahan dengan jumlah ibu bersalin sebanyak 494 orang (Data PWS KIA, puskesmas Aek Songsongan, 2012). Penetapan ibu bersalin 3 bulan terakhir sebagai populasi dengan pertimbangan informasi tentang perawatan kehamilan dan keterkaitan diskriminasi gender terhadap pemilihan penolong persalinan (akses pelayanan kesehatan, pengambilan keputusan) akan lebih banyak didapatkan. Besar sampel dalam penilitian ini sebanyak 94 orang.

Pengambilan sampel dilakukan dengan metode purposive samplingyaitu mengambil sampel berdasarkan 
pertimbangan yang dibuat oleh peneliti, berdasarkan ciri atau sifat-sifat populasi yang sudah diketahui sebelumnya.

\section{ANALISIS DATA}

Analisis data dilakukan melalui 3 tahapan, yaitu

1. Analisis univariat, untuk menggambarkan karakteristik masing-masing variabel yang diteliti dengan menggunakan distribusi frekuensi dan persentase masing-masing kelompok, data ditampilkan dalam bentuk tabel distribusi frekuensi,

2. Analisis bivariat, untuk mengidentifikasi ada tidaknya hubungan antara 2 variabel, yaitu variabel bebas dan variabel terikat. Analisis menggunakan uji statistik chisquare $\left(\chi^{2}\right)$, dengan tingkat kemaknaan $p<0.05$ dan Confidence Interval (95\%) dan untuk melihat besarnya hubungan variabel independent dengan pemilihan penolong persalinan dengan melihat nilai prevalence ratio.

3. Analisis multivariat, untuk mengetahui pengaruh variable-variabel independent secara bersama-sama terhadap satu variabel dependen yang bersifat dikotomus, dan untuk mengetahui variabel mana yang paling berpengaruh terhadap variabel dependen pada taraf kepercayaan 95\%. Uji statistik yang digunakan adalah analisis multiple logistic regression (regresi logistik) dengan metode seleksi forward stepwise (conditional).

\section{HASIL DAN PEMBAHASAN \\ HASIL PENELITIAN}

\section{Deskripsi Kecamatan Bandar Pulau Kabupaten Asahan}

Kecamatan Bandar Pulau merupakan kecamatan yang kondisi geografis perbukitan, sarana transportasi yang sulit, tingkat pendidikan dan sosial ekonomi yang masih rendah, terdiri dari dari 10 desa dan 60 dusun dengan luas daerah $433.342\left(\mathrm{Km}^{2}\right)$ serta jumlah penduduknya yang lebih banyak yaitu 20.508 jiwaterdiri dari 9.548 jiwa laki-laki, 10.285 jiwa perempuan dan 4.812 kepala keluarga dan terbagi dalam 10 desa, kecamatan Bandar Pulau mempunyaijumlah penduduk terbanyak di bandingkan dengan Kecamatan Aek Songsongan dan Kecamatan Rahuning.

Kecamatan Bandar Pulau mempunyai 4 Puskesmas Pembantu (Pustu) dengan 4 orang bidan Pustu, dan 7 orang bidan desa. Empat orang bidan desa menetap tinggal di wilayah kerjanya sedangkan 2 orang bidan desa menetap tinggal di luar wilayah kerjanya. Jumlah dukun yang terdapat di kecamatan Bandar Pulau sebanyak 20 orang dukun terdiri dari 7 orang dukun terlatih dan 13 orang dukun tidak terlatih.Sarana pelayanan kesehatan dan tenaga kesehatan yang berperan dalam peningkatan derajat kesehatan masyarakat di kecamatan Bandar Pulau adalahPuskesmas Aeksongsongan. Berdasarkan data yang diterbitkan Badan Pusat Statistik Penduduk di wilayah kerja Puskesmas Aeksongsongan yang membawahi 3 kecamatan, yaitu kecamatan Aeksongsongan, kecamatan Rahuning dan kecamatan Bandar Pulau dengan jumlah penduduk sebanyak 54.502 jiwa per km2 dengan jumlah penduduk laki-laki sebayak 27.668 jiwa dan perempuan 26.834 jiwa.Sesuai dengan standar Indonesia Sehat 2010,1 puskesmas melayani30.000jiwa,hal ini menggambarkan bahwa puskesmas Aeksongsongan belum sesuai dengan standar karena puskesmas Aek songsongan melayani 54.502 jiwa.

Berdasarkan Profil Kesehatan Puskesmas Aek Songsongan tahun 2010, cakupan pertolongan persalinan oleh tenaga kesehatan di kecamatan Bandar Pulau dari 10 desa, 5 desa sudah mencapai target cakupan pertolongan persalinan oleh tenaga kesehatan sesuai dengan visi Indonesia Sehat 2010 yaitu 90\%, namun 5 desa lagi belum mencapai target cakupan nasional.Secara rinci dapat dilihat pada tabel 1 . berikut:

Tabel 1. Deskripsi Kecamatan Bandar Pulau.

\begin{tabular}{|c|c|c|c|c|c|}
\hline No & Desa & $\begin{array}{c}\text { Dusu } \\
n\end{array}$ & $\begin{array}{c}\text { Jumlah } \\
\text { penduduk }\end{array}$ & Pustu & Bidan \\
\hline 1 & $\begin{array}{l}\text { Bandar } \\
\text { pulau } \\
\text { pekan }\end{array}$ & 4 & 1.536 & Ada & 1 \\
\hline 2 & $\begin{array}{l}\text { Padang } \\
\text { Pulau }\end{array}$ & 7 & 3.135 & - & 2 \\
\hline 3 & $\begin{array}{l}\text { Gunung } \\
\text { Berkat }\end{array}$ & 5 & 1.524 & Ada & 1 \\
\hline 4 & $\begin{array}{l}\text { Aek } \\
\text { Nagali }\end{array}$ & 6 & 2.037 & - & 1 \\
\hline 5 & $\begin{array}{l}\text { Perkebu } \\
\text { nan } \\
\text { Padang } \\
\text { Pulau }\end{array}$ & 4 & 507 & - & - \\
\hline 6 & $\begin{array}{l}\text { Gajah } \\
\text { Sakti }\end{array}$ & 5 & 1.724 & - & 1 \\
\hline 7 & $\begin{array}{l}\text { Buntu } \\
\text { Maraja }\end{array}$ & 6 & 1.372 & Ada & 1 \\
\hline 8 & $\begin{array}{l}\text { Gonting } \\
\text { Malaha }\end{array}$ & 6 & 2.979 & Ada & 2 \\
\hline 9 & Hutarao & 6 & 2.206 & - & 1 \\
\hline 10 & $\begin{array}{l}\text { Perkebu } \\
\text { nan } \\
\text { Aek } \\
\text { tarum }\end{array}$ & 11 & 3.488 & - & 1 \\
\hline
\end{tabular}

\section{Gambaran Karakteristik Responden}

Karakteristik responden pada penelitian ini meliputi umur istri, suku, pendidikan, pekerjaan, jumlah anak, umur suami, suku, pendidikan dan pekerjaan. Untuk lebih rinci dapat dilihat pada tabel berikut : 
Tabel 2. Distribusi Karakteristik Responden di Kecamatan Bandar Pulau Kabupaten Asahan Tahun 2013

\begin{tabular}{|c|c|c|c|}
\hline No & $\begin{array}{c}\text { Karakteristik } \\
\text { Responden }\end{array}$ & $\begin{array}{l}\text { Jumlah } \\
\text { (orang) }\end{array}$ & $\begin{array}{c}\text { Persentase } \\
(\%)\end{array}$ \\
\hline 1. & Umur & & \\
\hline a. & $15-19$ & 4 & 4,3 \\
\hline b. & $20-24$ & 14 & 14,9 \\
\hline c. & $25-29$ & 42 & 44,7 \\
\hline d. & $30-34$ & 24 & 25,5 \\
\hline e. & $35-39$ & 9 & 9,6 \\
\hline \multirow[t]{2}{*}{ f. } & $40-44$ & 1 & 1,1 \\
\hline & Jumlah & 94 & 100,0 \\
\hline \multirow{5}{*}{$\begin{array}{l}\text { a. } \\
\text { b. } \\
\text { c. }\end{array}$} & Suku & & \\
\hline & Jawa & 83 & 88,3 \\
\hline & Batak & 10 & 10,6 \\
\hline & Aceh & 1 & 1,1 \\
\hline & Jumlah & 94 & 100,0 \\
\hline \multirow{6}{*}{$\begin{array}{l}\text { a. } \\
\text { b. } \\
\text { c. } \\
\text { d. }\end{array}$} & Pendidikan & & \\
\hline & SD & 7 & 7,4 \\
\hline & SMP & 28 & 29,8 \\
\hline & SMU & 53 & 56,4 \\
\hline & Perguruan Tinggi & 6 & 6,4 \\
\hline & Jumlah & 94 & 100,0 \\
\hline \multirow[t]{4}{*}{4.} & Pekerjaan & & \\
\hline & Bekerja & 43 & 45,7 \\
\hline & Tidak bekerja & 51 & 54,3 \\
\hline & Jumlah & 94 & 100,0 \\
\hline \multirow[t]{4}{*}{5.} & Jumlah Anak & & \\
\hline & $\leq 2$ orang & 70 & 74,5 \\
\hline & $>2$ orang & 24 & 25,5 \\
\hline & Jumlah & 94 & 100,0 \\
\hline
\end{tabular}

Hasil penelitian menunjukkan sebagian besar responden berumur 20-34 tahun yang merupakan usia reproduktif dan usia yang sehat untuk seorang wanita melakukan tugas reproduksinya. Sebahagian besar responden bersuku Jawa. Sebagian besar responden berpendidikan SMU dan tidak bekerja. Jumlah anak yang dimiliki lebih banyak $\leq 2$ orang.

Tabel 3. Distribusi Karakteristik Suami di Kecamatan Bandar Pulau Kabupaten Langkat Tahun 2013

\begin{tabular}{clcc}
\hline No & $\begin{array}{c}\text { Karakteristik } \\
\text { Suami }\end{array}$ & $\begin{array}{c}\text { Jumlah } \\
\text { (orang) }\end{array}$ & Persentase (\%) \\
\hline 1. & Umur & & \\
a. & $20-24$ & 6 & 6,4 \\
b. & $25-29$ & 31 & 33,0 \\
c. & $30-34$ & 33 & 35,1 \\
d. & $35-39$ & 16 & 17,0 \\
e. & $40-44$ & 8 & 8,5 \\
\hline & Jumlah & $\mathbf{9 4}$ & $\mathbf{1 0 0 , 0}$ \\
\hline 2. & Suku & & \\
a. & Jawa & 80 & 85,1 \\
b. & Batak & 12 & 12,8 \\
c. & Minang & 1 & 1,1 \\
d. & Aceh & 1 & 1,1 \\
\hline & Jumlah & $\mathbf{9 4}$ & $\mathbf{1 0 0 , 0}$ \\
\hline
\end{tabular}

Tabel 3. (Lanjutan)

\begin{tabular}{cclcc}
\hline No & $\begin{array}{c}\text { Karakteristik } \\
\text { Suami }\end{array}$ & $\begin{array}{c}\text { Jumlah } \\
\text { (orang) }\end{array}$ & $\begin{array}{c}\text { Persentase } \\
\text { (\%) }\end{array}$ \\
\hline 3. & & Pendidikan & & \\
& a. & SD & 9 & 9,6 \\
& b. & SMP & 24 & 25,5 \\
& c. & SMU & 53 & 56,4 \\
& d. & Perguruan & 8 & 8,5 \\
& & Tinggi & & \\
\hline & & Jumlah & $\mathbf{9 4}$ & $\mathbf{1 0 0 , 0}$ \\
\hline 4. & & Pekerjaan & & \\
& a. & Petani & 50 & 53,2 \\
& b. & Buruh & 14 & 14,9 \\
& c. & Pegawai & 14 & 14,9 \\
& & Swasta & & \\
& d. & Pedagang & 13 & 13,8 \\
e. & Pegawai & 3 & 3,2 \\
& Negeri Sipil & & \\
\hline & & Jumlah & $\mathbf{9 4}$ & $\mathbf{1 0 0 , 0}$ \\
\hline
\end{tabular}

Hasil penelitian menunjukkan sebagian besar suami berumur 25-34 tahun yang merupakan usia produktif. Sebagian besar suami bersuku Jawa. Suami lebih banyak berpendidikan SMU dan bekerja sebagai petani. Keadaan ini juga menggambarkan masih kurangnya kesejahteraan hidup dari keluarga responden.

\section{Distribusi Diskriminasi Gender dalam Keluarga dan Pemilihan Penolong Persalinan}

Untuk mengetahui distribusi diskriminasi gender dalam keluarga dan pemilihan penolong persalinan dilakukan analisis univariat dan disajikan dalam tabel disribusi fekuensi.

\section{A. Diskriminasi Gender dalam Keluarga}

Dari hasil uji analisis univariat terhadap diskriminasi gender dalam keluarga meliputi variabel akses pelayanan kesehatan dan pengambilan keputusan didapatkan hasil sebagai berikut:

a. Akses Pelayanan Kesehatan

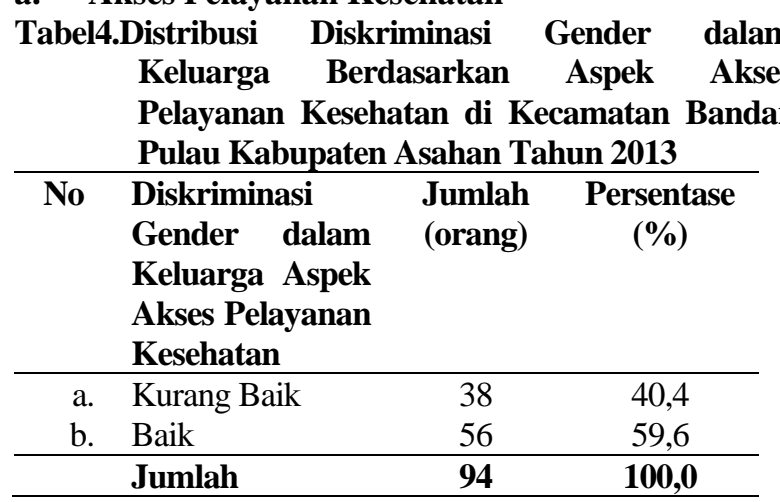

Dari Tabel di atas dapat diketahui bahwa diskriminasi gender dalam keluarga berdasarkan aspek akses pelayanan kesehatan di Kecamatan bandar Pulau Kabupaten Asahan sebagian besar baik, hal ini menggambarkan mudahnya responden untuk mengakses dan mendapatkan pelayanan kesehatan. 
b. Pengambilan Keputusan

Tabel 5. Distribusi Diskriminasi Gender dalam Keluarga Berdasarkan Aspek Pengambilan Keputusan di Kecamatan Bandar Pulau Kabupaten Asahan Tahun 2013

\begin{tabular}{|c|c|c|c|}
\hline No & $\begin{array}{l}\text { Diskriminasi Gender } \\
\text { dalam Keluarga } \\
\text { Aspek } \\
\text { Pengambilan } \\
\text { Keputusan }\end{array}$ & $\begin{array}{l}\text { Jumlah } \\
\text { (orang) }\end{array}$ & $\begin{array}{c}\text { Persentase } \\
\text { (\%) }\end{array}$ \\
\hline & a.Kurang Baik & 40 & 42,6 \\
\hline & D.Baik & 54 & 57,4 \\
\hline & Jumlah & 94 & 100,0 \\
\hline
\end{tabular}

Dari tabel di atas dapat diketahui bahwa diskriminasi gender dalam keluarga berdasarkan pengambilan keputusan di Kecamatan Bandar Pulau Kabupaten Asahan sebagian besar baik. Hal ini menggambarkan sudah baiknya pembagian peran sebagai istri dan peran sebagai suami dalam pengambilan keputusan.

\section{B. Pemilihan Penolong Persalinan}

Distribusi frekuensi responden berdasarkan pemilihan penolong persalinan di Kecamatan Bandar Pulau Kabupaten Asahan Tahun 2013 dapat dilihat pada tabel berikut ini:

Tabel 6. Distribusi Pemilihan Penolong Persalinan di Kecamatan Bandar Pulau Kabupaten Asahan Tahun 2013

\begin{tabular}{lcc}
\hline No Penolong Persalinan & $\begin{array}{c}\text { Jumlah } \\
\text { (orang) }\end{array}$ & $\begin{array}{c}\text { Persentase } \\
\text { (\%) }\end{array}$ \\
\hline 1. Non Tenaga Kesehatan & 15 & 16,0 \\
2. Tenaga Kesehatan & 79 & 84,0 \\
\hline \multicolumn{1}{c}{ Jumlah } & $\mathbf{9 4}$ & $\mathbf{1 0 0 , 0}$ \\
\hline
\end{tabular}

Dari tabel di atas menunjukkan sebagian besar responden memilih penolong persalinan dengan tenaga kesehatan sebanyak 84,0\%. Keadaan ini menunjukkan sebagian kecil responden istri masih memilih non tenaga kesehatan sebagai penolong persalinan yang dapat menimbulkan komplikasi pada saat bersalin dan nifas.

\section{Hubungan Diskriminasi Gender dalam Keluarga dengan Pemilihan Penolong Persalinan \\ Untuk mengetahui hubungan antara diskriminasi gender dalam keluarga (akses ke pelayanan kesehatan dan pengambilan keputusan) dengan pemilihan penolong persalinan dilakukan analisis bivariat dengan menggunakan uji chi-square dan hasil pengolahan data disajikan pada tabel silang.}

a. Hubungan Diskriminasi Gender dalam Keluarga Aspek Akses Pelayanan Kesehatan dengan Pemilihan Penolong Persalinan di Kecamatan Bandar Pulau Kabupaten Asahan Tahun 2013

Tabulasi silang hubungan diskriminasi gender dalam keluarga aspek akses pelayanan kesehatan dengan pemilih penolong persalinan dapat dilihat pada tabel berikut ini.

Tabel 7. Tabulasi Silang Hubungan Diskriminasi Gender dalam Keluarga Aspek Akses Pelayanan Kesehatan dengan Pemilihan Penolong Persalinan di Kecamatan Bandar Pulau Kabupaten Asahan tahun 2013

\begin{tabular}{|c|c|c|c|c|c|c|c|}
\hline Diskriminasi & & olong 1 & Persa & linan & & & \\
\hline $\begin{array}{l}\text { Gender dala } \\
\text { keluarga aspe }\end{array}$ & $\begin{array}{l}\text { Non } \\
\text { Kes }\end{array}$ & $\begin{array}{l}\text { tenaga } \\
\text { hatan }\end{array}$ & $\begin{array}{r}\text { TeI } \\
\text { Kese }\end{array}$ & $\begin{array}{l}\text { naga } \\
\text { hatan }\end{array}$ & Jum & DD & $5 \% \mathrm{C}$ \\
\hline $\begin{array}{l}\text { Akses } \\
\text { Pelayanan } \\
\text { Kesehatan }\end{array}$ & $\mathbf{n}$ & $\%$ & n & $\%$ & lah & & I \\
\hline Kurang Baik & 12 & 31,6 & 26 & 68,4 & 38 & 1,383 & $\begin{array}{l}1,105-, 001 \\
1,732\end{array}$ \\
\hline Baik & 3 & 5,4 & 53 & 94,6 & 56 & & \\
\hline
\end{tabular}

Dari hasil penelitian menunjukkan bahwa terdapat perbedaan persentase pemilihan penolong persalinan non tenaga kesehatan pada responden yang memiliki akses pelayanan kesehatan kurang baik (31,6\%), sedangkan responden memiliki akses pelayanan kesehatan baik (5,4\%).

Hasil uji statistik dengan uji chi-square menunjukkan ada hubungan yang signifikan antara akses pelayanan kesehatan dengan pemilihan penolong persalinan $(p=0,001)$, dengan nilai prevalence ratio $(P R)=1,383$ artinya responden yang mengalami diskriminasi gender dalam keluarga yaitu aspek akses pelayanan kesehatan kurang baik mempunyai kemungkinan 1,383 kali lebih besar memilih penolong persalinan non tenaga kesehatan dibandingkan dengan responden yang memiliki akses pelayanan kesehatan baik.

b. Hubungan Diskriminasi Gender dalam Keluarga Aspek Pengambilan Keputusan dengan Pemilihan Penolong Persalinan di Kecamatan Bandar Pulau Kabupaten Asahan Tahun 2013

Tabulasi silang hubungan diskriminasi gender dalam keluarga aspek pengambilan keputusan dengan pemilihan penolong persalinan dapat dilihat pada tabel berikut ini.

Tabel 8.Tabulasi Silang Hubungan Diskriminasi Gender dalam Keluarga Aspek Pengambilan Keputusan dengan Pemilihan Penolong Persalinan di Kecamatan Bandar Pulau Kabupaten Asahan Tahun 2013

\begin{tabular}{|c|c|c|c|c|c|c|c|}
\hline \multirow{4}{*}{$\begin{array}{l}\text { Diskriminasi } \\
\text { Gender dalam } \\
\text { Aspek } \\
\text { Pengambilan } \\
\text { Keputusan } \\
\end{array}$} & \multirow{2}{*}{\multicolumn{3}{|c|}{$\begin{array}{c}\text { Penolong } \\
\text { Persalinan }\end{array}$}} & \multirow{4}{*}{ Jumlah } & \multirow{4}{*}{ PR } & \multirow{4}{*}{$\begin{array}{c}95 \% \\
\text { CI }\end{array}$} & \multirow{4}{*}{$p$} \\
\hline & & & & & & & \\
\hline & \multicolumn{2}{|c|}{$\begin{array}{c}\text { Non } \\
\text { Nakes }\end{array}$} & Nakes & & & & \\
\hline & $\mathbf{n}$ & $\%$ & $\%$ & & & & \\
\hline Kurang Baik & 12 & $30 \quad 28$ & 70,0 & 40 & 1,349 & $\begin{array}{c}1,090- \\
1,669\end{array}$ & 0,001 \\
\hline Baik & 3 & $5,6 \quad 51$ & 94,4 & 54 & & & \\
\hline
\end{tabular}

Dari hasil penelitian menunjukkan bahwa terdapat perbedaan persentase pemilihan penolong persalinan non tenaga kesehatan pada responden yang memiliki pengambilan keputusan kurang baik (30,0\%), 
sedangkan responden memiliki pengambilan keputusan baik (5,6\%).

Hasil uji statistik dengan uji chi-square menunjukkan ada hubungan yang signifikan antara diskriminasi gender dalam keluraga aspek pengambilan keputusan dengan pemilihan penolong persalinan $(p=0,001)$, dengan nilai prevalence ratio $(\mathrm{PR})=1,349$ artinya responden yang mengalami diskriminasi gender dalam keluarga aspek pengambilan keputusan kurang baik mempunyai kemungkinan 1,349 kali lebih besar memilih penolong persalinan non tenaga kesehatan dibandingkan dengan responden yang memiliki pengambilan keputusan baik.

\section{i. Pengaruh Diskriminasi Gender dalam Keluarga terhadap Pemilihan Penolong Persalinan}

Untuk mengetahui pengaruh diskriminasi gender dalam keluarga (akses pelayanan kesehatan dan pengambilan keputusan) terhadap pemilihan penolong persalinan secara bersama-sama dilakukan analisis multivariat dengan menggunakan uji regresi logistik ganda (multiple logistic regression). Untuk melakukan analisis multivariat, dilakukan beberapa langkah yaitu:

1. Melakukan pemilihan variabel yang potensial dimasukkan dalam model. Variabel yang dipilih sebagai kandidat adalah $\mathrm{p}<0,25$.

2. Selanjutnya dilakukan pengujian secara bersmasama dengan metode forward stepwise (conditional) untuk mengidentifikasi faktor yang berpengaruh terhadap pemilihan penolong persalinan.

Berdasarkan hasil analisis bivariat diperoleh semua variabel memiliki nilai probabilitas $(p)$ lebih kecil dari 0,25. Selanjutnya semua variabel tersebut dimasukkan dalam model, kemudian dianalisis secara multivariat.

Hasil analisis multivariat dengan uji regresi logistik ganda diperoleh hasil bahwa hanya satu variabel yang berpengaruh secara signifikan terhadap pemilihan penolong persalinan yaitu variabel akses ke pelayanan kesehatan dengan koefisien regresi $=-1,588$, $p=0,030$, sehingga dapat dinyatakan bahwa diskriminasi gender dalam keluarga aspek akses ke pelayanan kesehatan yang kurang baik akan meningkatakan angka pertolongan persalinan dengan non tenaga kesehatan. Selengkapnya dapat dilihat pada tabel berikut.

Tabel. 9. Hasil Analisis Multivariat Uji Regresi Logistik Ganda

\begin{tabular}{lcccc}
\hline \multicolumn{1}{c}{ Variabel } & B & $\boldsymbol{p}$ & $\mathbf{E x p ( B )}$ & $\mathbf{9 5 \% ~ C I ~}$ \\
\hline Akses Pelayanan & $-1,588$ & 0,030 & 0,204 & $0,049-0,858$ \\
$\begin{array}{l}\text { Kesehatan } \\
\text { Constant }\end{array}$ & $-0,416$ & & & \\
\hline
\end{tabular}

\section{b. Pembahasan}

\subsubsection{Pemilihan Penolong Persalinan}

Dari hasil penelitian sebagian besar responden memilih tenaga kesehatan sebagai penolong persalinan
(84,0\%) di Kecamatan Bandar Pulau Kabupaten Asahan tahun 2013. Hal ini menunjukkan ibu sudah mengetahui persalinan yang aman sebaiknya dengan tenaga kesehatan. Fokus asuhan persalinan normal adalah persalinan bersih dan aman serta mencegah terjadinya komplikasi. Persalinan yang bersih dan aman memastikan setiap penolong persalinan mempunyai kemampuan, keterampilan dan alat untuk memberikan pertolongan persalinan yang aman. Ada lima dasar asuhan persalinan yang bersih dan aman, yaitu membuat keputusan klinik, asuhan sayang ibu dan sayang bayi, pencegahan infeksi, pencatatan dan mempersiapkan rujukan. Hasil penelitian juga menunjukkan sebagian kecil responden masih memilih non tenaga kesehatan sebagai penolong persalinan yang dapat menimbulkan komplikasi pada saat bersalin dan nifas.

Gambaran karakteristik responden dari hasil penelitian menunjukkan sebagian besar responden berumur 20-34 tahun yang merupakan usia reproduktif dan usia yang sehat untuk seorang wanita melakukan tugas reproduksinya. Sebagian besar responden bersuku Jawa, berpendidikan SMU dan tidak bekerja. Jumlah anak yang dimiliki lebih banyak $\leq 2$ orang. Sedangkan karakteristik suami menunjukkan sebagian besar suami berumur 25-34 tahun yang merupakan usia produktif. Sebahagian besar responden suami bersuku Jawa. Suami lebih banyak berpendidikan SMU dan bekerja sebagai petani. Keadaan ini juga menggambarkan masih rendahnya kesejahteraan kehidupan dari keluarga responden.

Penelitian yang dilakukan Friati (2012) secara kualitatif menemukan bahwa pemilihan Bidan Desa sebagai penolong persalinan dipengaruhi oleh hubungan kedekatan antara anggota keluarga, peran individu dalam keluarga, peranan pasangan hidup, akses geografis yang terjangkau, akses ekonomi yang terjangkau, akses sosial atau budaya yang dapat diterima oleh masyarakat, pengetahuan ibu yang cukup memadai dan pengetahuan Bidan Desa yang baik.

Masalah mendasar yang sering menjadi kendala dalam peningkatan kesehatan perempuan adalah sering terjadinya nilai-nilai sosial budaya yang menempatkan posisi perempuan pada posisi subordinatif yaitu stereotip masyarakat terhadap peran dan kedudukan perempuan (Sumaryoto, 2003).

Menurut Manuaba (2001) peningkatan pelayanan antenatal care, penerimaan gerakan keluarga berancana, melaksanakan persalinan bersih dan aman (pelayanan kebidanan dasar), dan meningkatkan pelayanan obstetric essensial dan darurat yang merupakan pelayanan kesehatan primer. Tidak jarang ibu hamil yang kritis meninggal sesampai di rumah sakit, artinya si ibu terlambat mendapatkan pertolongan. Kejadian ini dapat berupa kasus kelainan letak janin, hipertensi, perdarahan (rupture uteri) karena dukun bayi terlatih mendorong janin keluar rahim. Dalam keadaan kritis ditangan dukun bayi terlatih barulah si ibu dirujuk ke rumah sakit. 


\subsubsection{Pengaruh Diskriminasi Gender dalam Keluarga terhadap Pemilihan Penolong Persalinan}

\section{Akses Pelayanan Kesehatan}

Akses pelayanan kesehatan merupakan peluang atau kesempatan untuk menggunakan pelayanan kesehatan yang ada yang mencakup izin dan persetujuan dari suami terhadap istri dalam memilh penolong persalinan, kemampuan istri memilih penolong persalinan terkait dengan perannya sebagai istri dan ibu dalam keluarga, serta pelayanan petugas kesehatan dalam asuhan kehamilan/persalinan.

Dari hasil penelitian menunjukkan bahwa diskriminasi gender dalam keluarga berdasarkan akses pelayanan kesehatan di Kecamatan Bandar Pulau Kabupaten Asahan sebagian besar baik (59,6\%). Berdasarkan hasil analisis menggunakan uji chi-square menunjukkan ada hubungan yang signifikan antara diskriminasi gender dalam keluarga aspek akses pelayanan kesehatan dengan pemilihan penolong persalinan $(p=0,001)$. Hasil analisis pengaruh diskriminasi gender dalam keluarga berdasarkan akses pelayanan kesehatan terhadap pemilihan penolong persalinan menggunakan uji regresi logistik ganda menunjukkan ada pengaruh secara bermakna $(p=0,030)$ dengan koefisien regresi $=-1,588$, sehingga dapat dinyatakan bahwa diskriminasi gender dalam keluarga aspek akses ke pelayanan kesehatan yang kurang baik akan meningkatakan angka pertolongan persalinan dengan non tenaga kesehatan.Hal ini dimungkinkan karena kurangnya kesadaran dan pemahaman yang baik dari responden untuk memilih penolong persalinan dan berdasarkan jawaban responden terhadap kuesioner akses pelayanan kesehatan didapatkan bahwa masih kurangnya keterlibatan suami dalam menyediakan fasilitas yang dibutuhkan istri untuk memeriksakan kehamilan dan pertolongan persalinan ke pelayanan kesehatan.

Hasil penelitian ini sejalan dengan hasil penelitian yang dilakukan Akmal (2003) secara kualitatif di Kecamatan Sentani Kabupaten Jayapura, bahwa beratnya beban kerja, kemiskinan dan kurangnya dukungan suami dalam memotivasi ibu hamil untuk melakukan antenatalcare, serta kurangnya kemauan para suami untuk mengerjakan pekerjaan domestik, pengetahuan warisan yang diperoleh keluarga serta peran dukun bersalin, telah mengkondisikan ibu hamil untuk memilih memeriksakan kandungan dan mempercayakan persalinan kepada dukun bersalin.

Hasil penelitian didukung oleh teori menurut Azwar(2001), bahwa ketidaksetaraan gender terlihat dari adanya hambatan dalam akses pelayanan terhadap pelayanan kesehatan terutama dialami oleh perempuan karena adanya status perempuan yang tidak mendapat izin dari suami sebagai pemegang keputusan, siapa yang menolong persalinan istri kebanyakan masih ditentukan oleh suami, sehingga terjadi subordinasi terhadap perempuan dengan keterbatasan perempuan dalam pengambilan keputusan untuk kepentingan dirinya. Lebih praktisnya dapat dinyatakan bahwa perempuan berhak mengambil keputusan untuk memperoleh pelayanan kesehatan yang dibutuhkannya.

Angka kematian ibu dan bayi berkait dengan indikator, yaitu : terbatasnya akses masyarakat terhadap fasilitas pelayanan kesehatan yang berkualitas, terutama bagi penduduk miskin di daerah tertinggal, terpencil, perbatasan dan kepulauan. Penyediaan fasilitas pelayanan obstetrik neonatal emergensi komprehensif(PONEK), pelayanan obstetrik neonatal emergensi dasar (PONED), posyandu dan unittransfusi darah belum merata dan belum seluruhnya terjangkau oleh seluruh penduduk.Sistem rujukan dari rumah ke puskesmas dan ke rumah sakit juga belum berjalan denganoptimal. Ditambah lagi, dengan kendala geografis, hambatan transportasi, dan faktorbudaya. Terbatasnya ketersediaan tenaga kesehatan baik dari segi jumlah, kualitas danpersebarannya, terutama bidan petugas kesehatan di daerah terpencil sering kali tidak memperoleh pelatihan yang memadai.Masih rendahnya pengetahuan dan kesadaran masyarakat akan pentingnya menjagakesehatan dan keselamatan ibu. Indikator sosial ekonomi seperti tingkat ekonomi dan pendidikan yang rendah serta determinan faktor lainnya dapat mempengaruhi tingkat pemanfaatan pelayanan serta berkontribusi pada angka kematian ibu di Indonesia (Bappenas, 2010)

\section{Pengambilan Keputusan terhadap Kehamilan}

Pengambilan keputusan terhadap kehamilan mencakup penentuan perencanaan kehamilan, jumlah anak dalam keluarga, jarak kehamilan, tempat pemeriksaan kehamilan dan kebutuhan dana serta perlengkapan menjelang persalinan.

Dari hasil analisis penelitian ditemukan bahwa diskriminasi gender dalam keluarga berdasarkan pengambilan keputusan di kecamatan Bandar Pulau Kabupaten Asahan sebagian besar baik (57,4\%). Hasil analisis menggunakan uji chi-square menunjukkan ada hubungan yang signifikan antara pengambilan keputusan dengan pemilihan penolong persalinan $(p=0,001)$. Namun hasil analisis pengaruh diskriminasi gender dalam keluarga aspek pengambilan keputusan terhadap pemilihan penolong persalianan menggunakan uji regresi logistik ganda menunjukkan tidak ada pengaruh secara bermakna. Hal ini dimungkinkan karena sebagian besar responden istri berumur 20-34 tahun yang merupakan usia reproduktif. Sebagian besar responden istri tidak bekerja. Jumlah anak yang dimiliki lebih banyak dengan jumlah $\leq 2$ orang. Berdasarkan jawaban responden terhadap kuesioner pengambilan keputusan didapatkan pengambilan keputusan untuk perencanaan kehamilan, persiapan dana untuk pemeriksaan kehamilan dan persalinan serta perlengkapan untuk persalinan lebih banyak ditentukan atau diputuskan oleh suami. Hal ini menggambarkan perbedaan pendapat dari responden tentang peran sebagai istri dan peran sebagai suami dalam pengambilan keputusan.

Hasil penelitian sejalan dengan penelitian yang dilakukan Astari (2005) di Cianjur, bahwa pengambil 
keputusan dalam keluarga umumnya adalah suami, kecuali pada istri yang bekerja, istri mempunyai wewenang untuk mengambil keputusan. Proses pengambilan keputusan umumnya secara musyawarah. Meski hanya pada keluarga dengan istri bekerja keputusan diambil berdasarkan kesepakatan bersama.Sedangkan yang lainnya pengambilan keputusan dikembalikan pada pihak suami.

Hasil penelitian juga sejalan dengan penelitian yang dilakukan Nabuasa (2006) di Kupang, terdapat beberapa pola pengambilan keputusan dalam keluarga mengenai perencanan kehamilan yang meliputi keputusan dibuat bersama oleh suami istri tanpa ada dominan diantara keduanya, keputusan dibuat oleh suami istri dengan pengaruh suami lebih besar, dan keputusan dibuat oleh suami dan istri dengan pengaruh dari luar terutama dari mertua.

Hasil penelitian juga didukung oleh teori menurut Makarao (2009), bahwa kesetaraan gender dalam kesehatan terbagi atas kesetaraan dalam hak, kesetaraan dalam sumber daya dan kesetaraan dalam menyuarakan pendapat. Adanya kesetaraan hak dalam peran dan tanggung jawab laki-laki dan perempuan dalam bidang kesehatan seperti kesetaraan hak dalam rumah tangga yaitu perempuan dan laki-laki mempunyai hak yang sama dalam kesehatan, misalnya menentukan jumlah anak, jenis persalinan, pemilihan alat kontrasepsi, dan lain-lain. Selain itu, perempuan dan laki-laki mempunyai hak yang sama dalam pengambilan keputusan.

Menurut hasil kesepakatan Konferensi Kependudukan dan Pembangunan Internasional (ICPD) di Kairo tahun 1994, hak-hak reproduksi mencakup hak untuk hidup bebas dari resiko kematian karena kehamilan, hak atas kebebasan dan keamanan atas kehidupan reproduksinya, hak atas kesetaraan dan bebas dari segala bentuk diskriminasi, hak atas kerahasiaan pribadi, hak kebebasan berpikir, hak memilih bentuk keluarga dan untuk membangun serta merencanakan keluarga, hak untuk memutuskan secara bebas mengenai jumlah anak, menentukan waktu kelahiran anak dan cara untuk mernperolehnya (Depkes RI, 2005).

\section{KESIMPULAN DAN SARAN}

\section{Kesimpulan}

Berdasarkan hasil penelitian dan pembahasan dapat ditarik kesimpulan sebagai berikut:

1. Ada pengaruh diskriminasi gender dalam keluarga aspek akses pelayanan kesehatan terhadap pemilihan penolong persalinan secara signifikan sehingga dapat dinyatakan bila akses ke pelayanan kesehatan kurang baik maka semakin tinggi angka pertolongan persalinan dengan non tenaga kesehatan.

2. Tidak ada pengaruh diskriminasi gender dalam keluarga aspek pengambilan keputusan terhadap pemilihan penolong persalinan.

\subsection{Saran}

1. Diharapkan petugas kesehatan di puskesmas Aek Songsongan dan bidan di desa dapat memberikan pendidikan kesehatan (penyuluhan) pada pasangan usia subur tentang peran (gender) laki-laki dan perempuan dalam keluarga khususnya keterlibatan suami dalam menyediakan fasilitas yang dibutuhkan istri untuk memeriksakan kehamilan dan pertolongan persalinan ke pelayanan kesehatan dan pengambilan keputusan untuk perencanaan kehamilan, persiapan dana untuk pemeriksaan kehamilan dan persalinan serta perlengkapan untuk persalinan lebih banyak ditentukan oleh suami sehingga dapat mendukung pemilihan penolong persalinan kepada tenaga kesehatan, melalui kegiatan KIE (komunikasi, informasi dan edukasi), promosi atau kampanye langsung ke masyarakat melalui lintas sektoral dengan melibatkan tokoh agama dan tokoh masyarakat.

2. Diharapkan anggota keluarga dan masyarakat dapat meningkatkan pengetahuan dan wawasan tentang gender (peran) antara laki-laki dan perempuan sehingga tercipta kesetaraan gender untuk mendukung peningkatan status sosial perempuan di dalam keluarga dan masyarakat yang pada akhirnya akan terwujud kesehatan reproduksi yang lebih baik.

\section{DAFTAR PUSTAKA}

Abdullah, I., 2001. Seks, Gender \& Reproduksi Kekuasaan, Yogyakarta : Tarawang Press.

Akmal, Y., 2003, Kondisi Sosial Budaya Suku Sentani dan Implikasinya pada Perilaku Ibu Hamil dalam Memanfaatkan Pelayanan Program Kesehatan Ibu dan Anak (KIA) di Puskesmas: Studi Kasus di Kecamatan Sentani, Kabupaten Jayapura, (Tesis); Program S2 FIK Universitas Indonesia,: http:www.lontar.ui.ac.id, diakses tanggal 21 Juni 2013.

Astari, A.M., 2005, Studi Kualitatif Pengambilan Keputusan dalam Keluarga Terkait dengan Komplikasi Perinatal di Kabupaten Cianjur Jawa Barat, (Tesis); Program Studi S2 Keperawatan Maternitas Universitas Indonesia,: http:www.lontar.ui.ac.id, diakses tanggal 21 Juni 2013.

Azwar, A., 2001. Bagaimana Mengatasi Kesenjangan Jender. Jakarta: Kantor Negara Pemberdayaan Perempuan.

Bappenas, 2007. Rencana Jangka Menengah Pembangunan Kesehatan Indonesia, Jakarta

2010 Laporan Pencapaian Tujuan Pembangunan Milenium Indonesia 2010, Kementrian Perencanaan Pembangunan Nasional , Jakarta 
Darwizar. A 2002. Manajemen Terpadu Bayi Muda dan Manajemen Terpadu Balita Sakit, Suara Pembaharuan, Jakarta

Depkes, 1993, Pedoman Pelatihan Dukun Bayi, Direktorat Jenderal Pembinaan Kesehatan Masyarakat, Direktorat Bina Kesehatan Keluarga, Jakarta. 1998. Modul Safe Motherhood. (kerjasama Depkes RI-WHO dan FKM UI, Jakarta. 2003. Program Penanggulangan Anemia Gizi Pada Wanita Usia Subur (WUS), Direktorat Gizi Masyarakat, Direktorat Jenderat Bina Kesehatan Masyarakat, Jakarta.

, 2005. Rencana Strategis Departemen Kesehatan Tahun 2005 - 2009, Jakarta

Dinkes Provinsi Sumatera Utara, 2010, Profil Kesehatan Provinsi Sumatera Utara, tahun 2010, Medan

Dinkes Kab.Asahan, 2010. Profil Kesehatan Kabupaten Asahan tahun 2010, Kisaran

Frianti, S.G., 2012, Pengambilan Keputusan Keluarga terhadap Pemilihan Bidan Desa sebagai Penolong Persalinan di Kecamatan Samudera Kabupaten Aceh Utara, (Tesis); Program Studi S2 IKM FKM Universitas Sumatera Utara, http:www.repository.usu.ac.id, diakses tanggal 21 September 2013.

Handayani, T., dan Sugiarti, 2002, Konsep dan Teknik Penelitian Gender, Malang : Universitas Muhammadiyah Malang.

Hidayat, M., 2005. Komunikasi Pengambilan Keputusan untuk Pemeliharaan Kesehatan Reproduksi pada Ibu-ibu Rumah Tangga di Pedesaan, Bandung : Fakultas Ilmu Komunikasi UNPAD.

Lemeshow, S., Hosmer, Jr, D, W., Klar, J. \& Lwanga, S. K. 1997. Besar sampel dalam penelitian kesehatan. Penerjemahan: Pramono, D. Yogyakarta:Gadjah Mada University Press.

Makarao, N.R., 2009, Gender Dalam Bidang Kesehatan, Bandung : Alfabeta.

Manuaba, IBG., 2001, Ilmu Kebidanan Penyakit Kandungan dan Keluarga Berencana untuk Pendidikan Bidan, EGC, Jakarta.

Megawangi, R., 1999, Membiarkan Berbeda? : Sudut Pandang Baru tentang Relasi Gender, Bandung: Mizan.

Mosse, J.C., 1996. Gender dan Pembangunan, Edisi Bahasa Indonesia, Yogyakarta: Pustaka Pelajar.

Nabuasa, E., 2006, Dukungan Suami Terhadap Istri Selama Masa Kehamilan, Persalinan, dan Masa Nifas Berdasarkan Etnis Studi di Wilayah Kerja Puskesmas Pasir Panjang Kota Kupang, Hasil Penelitian; Majalah Kesehatan Masyarakat vol.01.No.01 Desember 2006 38-50.

Notoatmodjo, S, 2005, Ilmu Perilaku Kesehatan. Jakarta : Rineka Cipta, Jakarta. 2006. Metodologi Penelitian Kesehatan (Edisi Revisi). Rineka Cipta, Jakarta.

Puskesmas Aek Songsongan, 2012. Rekapitulasi Laporan PWS KIA Bulan Desember 2012.

Resty K. 2003. Fungsi Ibu Sulit Diganti, Fungsi Isteri Dapat Diganti http://www.promosikesehatan.com

Riwidikdo, H., 2008, Statistik Kesehatan, Belajar Mudah Tehnik Analisis Data dalam Penelitian Kesehatan (Plus Aplikasi Software SPSS), Yogyakarta: Mitra Cendikia Press.

Sibagariang, E.E., Pusmaika, R., Rismalinda., 2010. Kesehatan Reproduksi Wanita, Jakarta : CV. Trans Info Media.

Sumarnyoto., 2003. Pelayanan Bayi-Bayi Keluarga Miskin Yang Harus Dirawat Di Ruang Intensive Care Unit (ICU) RSAB Harapan Kita, Jakarta 